\title{
STUDY ON EXPERT STATUS IN THE EUROPEAN JUDICIAL SYSTEM
}

\author{
Gh. Popa, I. Necula
}

\section{Gheorghe Popa}

Romanian-American University, Bucharest, Romania, *Correspondence: Popa Gheorghe, 1B Expoztiei Blvd., Sector 1, Bucharest, Romania E-mail: popa_gheorghe1959@yahoo.com

\section{Ionel Necula}

National Forensic Science Institute, Bucharest, Romania, *Correspondence: Ionel Necula, National Forensic Science Institute, 13-15 Ştefan cel Mare St., Sector 2, Bucharest, Romania

\begin{abstract}
In some European countries, expert status is defined by the legislation, whereas, in others, by the membership of a professional group or specialized institution under the Ministry of Justice and Police, this subordination being of a financial nature, without affecting the expertise itself.

This article contain a point of view regarding the European judicial system, the term expert's different meanings and the criteria that define an expert's status and which are different from one state to another.
\end{abstract}

Keywords: expert, status, system, European juridical system

\section{Introduction}

Previously, in 1959 the European Convention on Mutual Assistance in Criminal Matters had dealt with this matter quite summarily and only in relation to criminal matters (letter rogatory requests for expert examination, summoning experts).

The issue of forensic experts is currently being considered at the level of the European Network of Forensic Science Institutes (ENFSI) with a view to setting up a European expert status, governed by a process of accreditation and validation in accordance with ethical standards and rules of conduct ${ }^{1}$.

I. In some European countries, expert status is defined by the legislation, whereas, in others, by the membership of a professional group or specialized institution under the Ministry of Justice and Police, this subordination being of a financial nature, without affecting the expertise itself.

Thus, there are several types of experts involved in solving cases. Some of them belong to specialized laboratories, others are independent experts enrolled or not on national lists who are subject to regular assessments or they are only qualified people, not experts in the strict sense.

In some European countries (France, Romania, United Kingdom, etc.), the expert status is granted by an independent institution, either through recognition by the judiciary, by meeting certain criteria, or through inclusion on an official list/nominal table. For example, in

\footnotetext{
${ }^{1}$ Code of Conduct for forensic practitioners developed at the level of ENFSI, "CODE of CONDUCT" (BRDGEN-003/16.6/2005).
} 
France experts are included on a list displayed in each court of justice and a national list on the website of the Court of Cassation, and here accreditation refers to the laboratories' methodology and management, whereas certification refers to the individual expert.

In Latvia there are two categories of experts, one including those who have specialized knowledge in a field and the other including experts who pass a series of tests given by a commission of representatives of the Ministry of Justice, Ministry of Interior, Public Ministry, the Police and experts in the field.

Regarding the issue of experts' independence, there are a number of rules specific to the prosecution stage and the trial stage.

In France, there are limitations with regard to the number of experts summoned for a particular field, as well as with regard to the expert working in the same professional field as the trial subjects. The expert report may be subject to examination by another expert as a guarantee of the former's correctness.

In Austria, if there are any doubts about an expert's independence, the Austrian Federal Court will decide whether or not the expert in question should participate in the criminal proceedings in that case. The list of qualified experts is available on the Internet. Sometimes, on basis of the judge's free evaluation, German experts, either of public or private institutions, are resorted to, at the expense of the convict, as the amounts to be paid are not excessive.

In Germany, the judge decides on the experts to be consulted and their number controls the expert's activity and presents the scientific rationale behind his/her decisions. Experts are mentioned on a list established at local level.

In the United Kingdom, expert independence has to do with scientific objectivity, there is a list of several thousand experts accredited by special Councils for expert accreditation in observance of strict professional rules and who can exercise their profession without any geographical limitations, expert independence being related to the judge's control and to the case file.

In Luxembourg, the law allows the judge to order the performance of the expertise by foreign experts if they are recognized in the State of origin.

In terms of expertise costs, when the analysis of scientific evidence is required, in less serious cases such costs may be high, especially if the expertise is done in private institutions instead of public institutions, therefore the financial restrictions that may limit the access of the defence to expertise services should be taken into consideration. In France, the cost of conducting an expertise is reported to the budget of the Ministry of Justice and in special cases it may be supplemented from the budget.

Sometimes the cost price can be a factor in the competition between expertise suppliers, thus it has been shown that the DNA analysis can be performed in less serious cases at a cost price lower than the cost of using investigative technologies such as telephone interception. An eloquent example is the expertise service in the United Kingdom of Great Britain, where $90 \%$ of the expertise consists in DNA analysis, which has led to the setting up under the aegis of the Home Office of a regulatory unit called "Forensic Regulator" which advises magistrates on expertise services and sets the rules for the operation of these services.

In Finland experts are selected from among police officers who have undergone a training programme of about six months with no duties in the crime scene research, the expert function being incompatible with that of investigator at the crime scene.

In Poland, there are forensic experts involved as consultants for gathering evidence at the crime scene, which is also the case in the Netherlands, for DNA or biological evidence collection, and in Denmark, where the presence of a private expert is sometimes required in cases of fire.

The experts' judicial training is aimed at having them know the place and role of expertise in the criminal proceedings, consisting in knowledge of the general rules of conduct of the criminal proceedings and specialized knowledge in their field of expertise. 
In the specialized literature there are various views on the capacity of expert ${ }^{2}$ :

- Gaining experience as an expert does not grant jurisdiction to act as an expert in other cases. Experience as an expert witness, standing alone, does not qualify someone as an expert in later cases. For example in Bogosian v. Mercedes-Benz of N.Am., Inc., 104F.3d 472, 477 (1st Cir.1997), the court rejected an opinion of a witness who had testified as an expert 126 times.

- The Court held that "it is absurd to conclude that one can become an expert through the experience accumulated by conducting expertises". One court even noted "it would be absurd to conclude that one can become an expert by accumulating experience in testifying" Thomas J. Kline, Inc. v. Lenillard, Inc., 878F.2d 791, 800 (4th Cir. 1989).

- Even the most experienced expert should have his first day as an expert before the court. In United States v. Locascio, 6 F.3d 924, 937 (2nd Cir. 1993), the court concluded that "...even the most qualified expert must have his first day in court".

The European Commission for the Efficiency of Justice, a body established by the Council of Ministers of the Council of Europe in September 2002 to assess the effeciency of judicial systems, drafted in 2012, on basis of data provided by the EU Member States (in 2010), a document on "European Judicial Systems: Efficiency and Quality of Justice"”.

In preparing this document a total of 47 states were involved that responded to this assessment process: Albania, Andorra, Armenia, Austria, Azerbaijan, Belgium, Bosnia and Herzegovina, Bulgaria, Croatia, Cyprus, the Czech Republic, Denmark, Estonia, Finland, France, Georgia, Germany, Greece, Hungary, Iceland, Ireland, Italy, Latvia, Lithuania, Luxembourg, Malta, the Republic of Moldova, Monaco, Montenegro, the Netherlands, Norway, Poland, Portugal, Romania, The Russian Federation, San Marino, Serbia, Slovakia, Slovenia, Spain, Sweden, Switzerland, "the former Yugoslav Republic of Macedonia", Turkey, Ukraine and the United Kingdom ${ }^{4}$.

The document states that "there is no consensus, no European Standards regarding judicial witnesses". Chapter 15 of this document entitled Judicial Experts highlights the role of judicial experts in improving judicial efficiency by providing judges with clear and reasoned responses regarding the specific and complex problems they face.

There are different kinds of judicial experts in the Member States of the Council of Europe, namely:

- Technical experts: those who provide the court with scientific and technical knowledge on matters of fact.

- Expert witnesses: those who are required by the parties to come up with their expertise in support of their argument.

- Court experts: those who can be consulted by judges in specific legal issues or are required to assist the judge in conducting the judicial work (but do not take part in the judgment).

It is noted that the concept of forensic expert is not included in this classification, the notion of judicial technical expert or forensic expert in the European legal space being treated rather like that of a witness or scientific witness ${ }^{5}$, a capacity granted by the parties or the judicial bodies, usually found in the form of a court expert (forensic expert). The missions of judicial experts may be different in certain countries, such as the Russian Federation, where

\footnotetext{
${ }^{2}$ Cătălin Grigoraş, Judicial Expertise in Europe and the ECHR Practice, Communication Symposium, "Novelties in the Field of Forensic Science, Criminal Law and Criminal Procedure", organized by the Romanian Forensic Association, Bucharest, 2009.

${ }^{3}$ www.coe.int/cepej

4 www.coe.int/cepej. European Comission for the Efficiency of Justice, Systèmes judiciaires européens, Efficacité et qualité de la justice, Les études de la CEPEJ no.18, Editions du Conseil de l'Europe, Publishing Editions 2012.

${ }^{5}$ Cătălin Grigoraş, Judicial Expertise in Europe and the ECHR Practice, Communication Symposium, "Novelties in the Field of Forensic Science, Criminal Law and Criminal Procedure", organized by the Romanian Forensic Association, Bucharest, 2009.
} 
a distinction is made between experts (who perform "expertises" and draw "expert reports"") and specialists (who assist in the performance of procedural activities and provide written or oral consultation).

In Switzerland the technical expert is used in the 26 cantons, the expert witness in 6 cantons and the court expert in 3 cantons.

Great Britain and Northern Ireland use expert witnesses. Liechtenstein and Great Britain - Scotland do not use judicial experts.

Technical expertise is used in 46 states. Liechtenstein, Great Britain - Northern Ireland and Great Britain - Scotland do not use it. Expertise by expert witnesses is used in 32 countries with common law systems and is found in the countries of northern Europe.

ECHR case-law on 11 December 2008 in the case Mirilashvili v. Russia (no. 6293/4) the Court in Strasbourg: reiterated that the judge is free to decide on the competence of an expert witness appointed by a party and found that the expert of the party was only allowed to express views on the conclusions drawn by the expert appointed by the prosecutor to conduct an audio expertise, not to participate effectively in its carrying out.

Judicial expertise is used in 8 states: Estonia, Germany, Ireland, Malta, Netherlands, Norway, Poland and the Russian Federation.

Courts have the freedom granted by law to choose the right experts. The Lisbon Treaty, Article 25 of Protocol 3, provides that "the Court of Justice may at any time entrust any individual, body, authority, committee or other organisation it chooses with the task of giving an expert opinion". There is a similar provision in Article 50 of the Statute of the International Court of Justice.

As regards the selection of judicial experts: they are appointed by the court (34 countries), the selection is performed directly by the Ministry of Justice or one of its components (12 countries: Azerbaijan, Hungary, Serbia, Slovenia, etc.), they are selected directly by the parties (Denmark, Ireland, Great Britain - England and Wales), they are appointed by the National Bureau of Judicial Expertise or private authorized legal entities (Georgia).

ECHR case-law on 16 February 2010 in the case V.D. v. Romania (no. 7078/02) the Court in Strasbourg: condemned Romania for breach of Art.6.3.d of the Convention. In this case the judicial bodies in Romania, including the courts, denied the party the right to perform forensic dactyloscopic and DNA analyses.

According to the requirements of the given procedure, the courts select experts from the official list at the Ministry of Justice (Bosnia and Herzegovina, Luxembourg, Slovakia, Sweden) or from a list of individuals recognized for their competence (Portugal) or by consent of the parties (Luxembourg, Portugal).

In Moldova, in judicial practice, through the judge's decision a specialized institution is identified which will decide on the appropriately qualified expert available at the time or any person may be summoned who possesses the knowledge needed to draw conclusions on the circumstances incurred in relation to a criminal case and which may have probative importance for the criminal case. (CPC, Art. 142 (3).

In the case of expert witnesses, before appointing them, the parties are heard in relation to the appointment.

In France (CPC, Art.157), Slovakia, Spain and Turkey, natural as well as legal persons included on the national list or of the Court of Cassation or on the lists of the Courts of Appeal can be registered as experts. As an exception, judicial bodies may also appoint experts from among people who are not on these lists.

In Germany, the expert is appointed according to his/her practical knowledge and experience in commenting on the facts and presenting expert opinions based on analyses and evaluation of the evidence presented in a fair, independent and objective manner, so that his/her views may be accepted by both parties. 
In the United Kingdom, the expert is a person who has knowledge or competence in a practical field 6 .

In Albania, the expert is designated from among specialists included in special lists or from among persons who have specific knowledge in a field, in Bulgaria, the act of expert appointment contains the objectives of the expertise, materials provided, name, education, academic rank, specialty, academic title and position of the expert or the institution in which the expert is employed, in Poland there are permanent experts of the Courts and persons known to have sufficient knowledge in a particular field may also be required to act as experts.

In Estonia, the authority in charge of selecting the expert depends on the matter, whatever the expert's mission may be. The judiciary may choose a judicial expert or an officially certified expert or any person who possesses the necessary knowledge, in Lithuania any person who has the necessary knowledge to express a conclusion can be appointed as an expert, in Finland, the court requires a declaration to this effect from an agency, a public official or another person known to be honest and competent.

In Montenegro, the experts are selected by a Commission established by the President of the Supreme Court, which is composed of five members (two judges, two representatives of the Association of Judicial Experts, one from the Ministry of Justice), in the Russian Federation, judges appoint individual experts and specialists or choose expert institutions based on views of the parties. In Switzerland, there is only one canton where the experts are not appointed ad hoc by the court in a case, but for a specified period.

In 2013 the European Commission for the Efficiency of Justice presented the results of the only study conducted in Europe, in 2010, regarding the number of experts per 100,000 capita, and the number of judges, the situation being displayed in the graphs below ${ }^{7}$ :

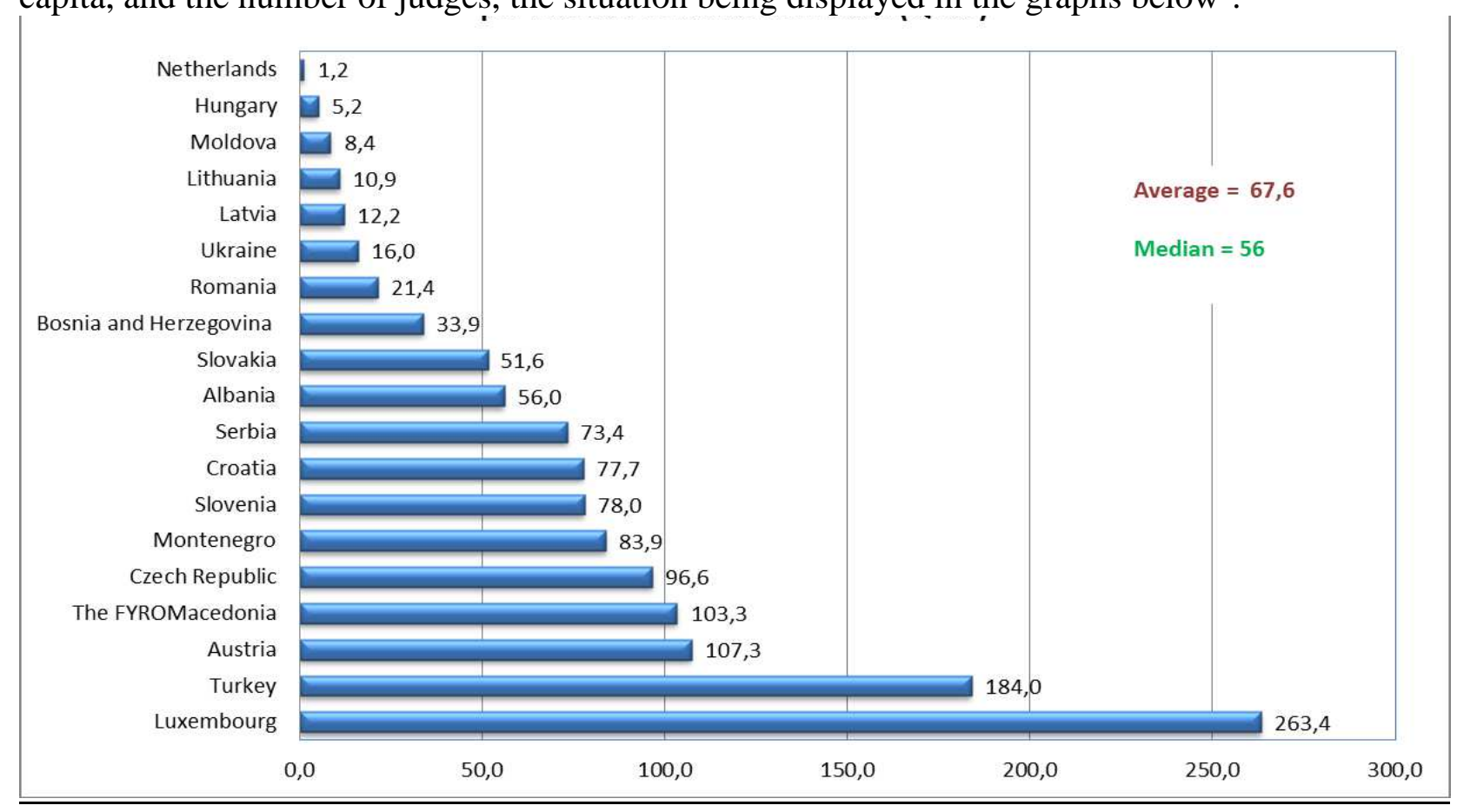

Number of experts per 100,000 capita

\footnotetext{
${ }^{6}$ Cătălin Grigoraş, Judicial Expertise in Europe and the ECHR Practice, Communication Symposium, "Novelties in the Field of Forensic Science, Criminal Law and Criminal Procedure", organized by the Romanian Forensic Association, Bucharest, 2009.

${ }^{7}$ European Comission for the Efficiency of Justice, "European Judicial Systems: Efficiency and Quality of Justice", 2012, www.coe.int/cepej.
} 


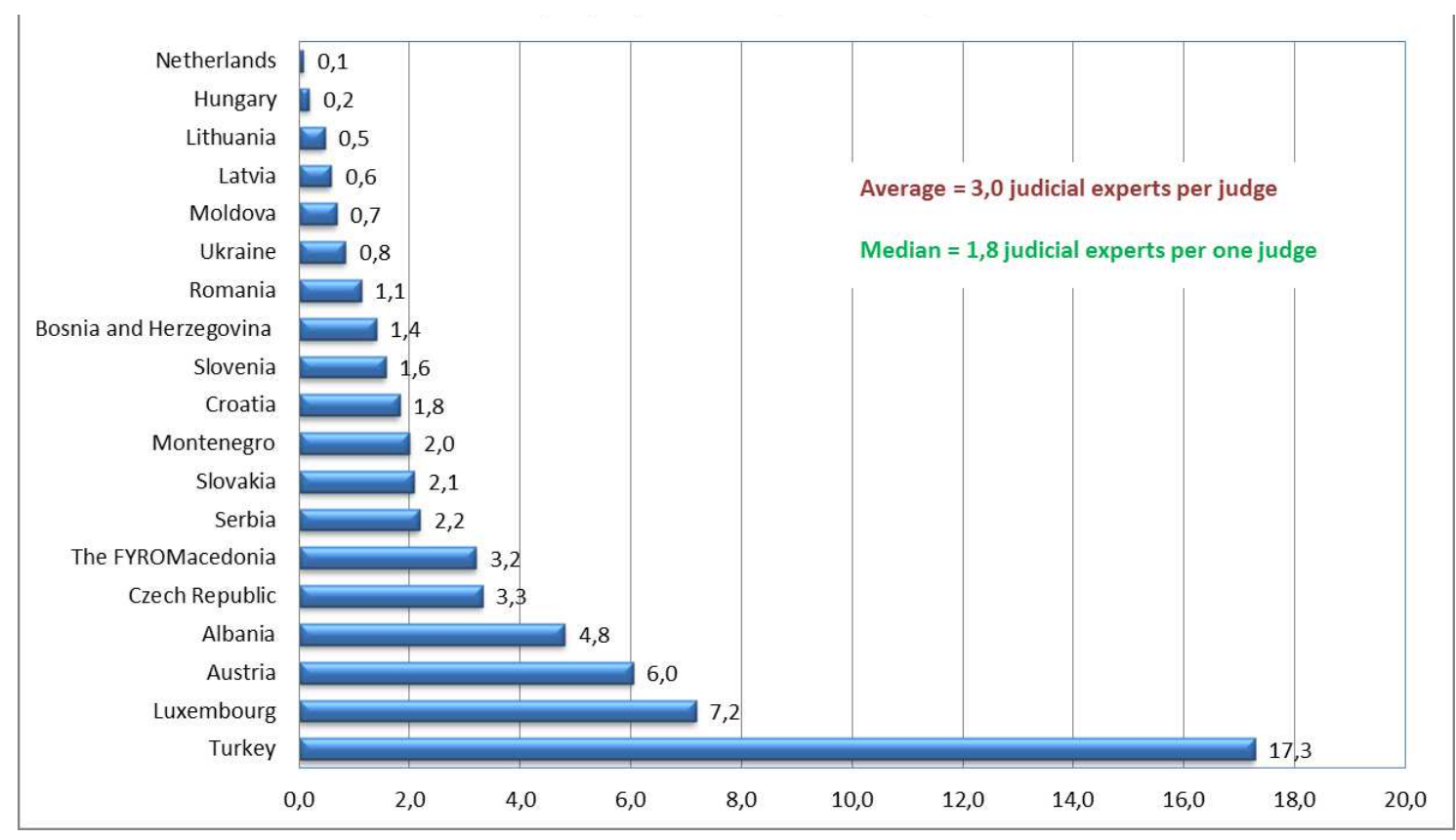

Number of technical experts in proportion to the number of judges in 2010

It is stated that, for the first time, in this study, mandatory criteria for exercising the position of a judicial expert as well as the protection of the judicial expert title and position were taken into consideration.

Thus, 36 states presented mandatory criteria for the capacity of judicial experts as regulated by their national law (Albania, Georgia, Germany, Greece, Iceland, Lithuania, Montenegro, Netherlands, Norway, Portugal, Romania, Russian Federation, Slovakia, Spain, "the former Yugoslav Republic of Macedonia", Turkey).

In some states, time limits for the performance of examinations by experts are provided (Albania, Austria, Bosnia and Herzegovina, Bulgaria, Finland, Greece, Hungary, Iceland, Ireland, Italy, Montenegro, Netherlands, Norway, Portugal, Serbia, Slovenia, Spain, "the former Yugoslav Republic of Macedonia", Great Britain - England and Wales), which in the Russian Federation and Ukraine are determined by judges.

Thus, three main options are highlighted:

- the time limit may be set by law to a maximum: in Albania, the maximum time varies between 16 days and 6 months; in Italy, the maximum is 60 days; in Portugal, 30 days; in "the former Yugoslav Republic of Macedonia”, between 45 and 60 days; in Turkey between 3 and 6 months;

- the time limit may be set by the judge if the law allows it, the judge being the one to decide the maximum time limit (the Russian Federation, Serbia, Slovakia, Great Britain England and Wales);

- the time limit may result from an agreement permitted by law, as in the Netherlands, where the Commissioner and the expert agree on the time period.

The new Romanian Criminal Procedure Code, Article 173, par. (7), provides the obligation of the expert "to produce an expert report in compliance with the deadline set in the order of the criminal prosecution body or in the court's ruling. The deadline mentioned in the order or the court's ruling may be extended at the request of the expert, for well-grounded reasons, without having the full extension granted exceed six months" and, in paragraph (8): "Unduly delay or refusal to perform the expertise entails the civil liability of the expert or the institution designated to perform it, for the damages caused". However, Art. 174, par. 1, provides that: "The expert can be replaced if he/she unduly fails to complete the expert report until the deadline, or if he/she manifests disinterest in the task entrusted to him/her" and, in par. 2, it is stated that, "the replacement is ordered, with summoning the expert, by order of 
the criminal prosecution body or by ruling of the court, which is communicated to the association or professional body to which the expert belongs. The expert replaced may be fined by the prosecutor or judge with a judicial fine of 500 to 5000 lei”.

There are regulations regarding the non-observance of the time limit for performing the expertise, the expert being punished with a fine of up to 1,000 euros (Montenegro), in other cases there are binding provisions on the need for an agreement regarding the DNA expertise (Belgium), further training (Slovakia), certain incompatibilities (Finland, Spain), expert's ethics (Great Britain - Northern Ireland), the requirements for registration as an expert (Slovakia).

In 28 states the judicial expert's title is protected and, in order to be appointed, he/she has to meet certain pre-conditions regarding his/her skills and moral behavior, the expert's work being followed by the judicial authorities.

In some states, there are associations/colleges of experts, some of them placed under the authority of the courts.

In 35 states, the experts guide themselves, in their expertise work, by national and international standards in the field.

\section{Conclusions}

The European Commission for the Efficiency of Justice, a body established by the Council of Ministers of the Council of Europe in September 2002 to assess the effeciency of judicial systems, drafted in 2012, on basis of data provided by the EU Member States (in 2010), a document on "European Judicial Systems: Efficiency and Quality of Justice".

The document states that "there is no consensus, no European Standards regarding judicial witnesses".

There are different kinds of judicial experts in the Member States of the Council of Europe, namely: technical experts, those who provide the court with scientific and technical knowledge on matters of fact; expert witnesses, those who are required by the parties to come up with their expertise in support of their argument; court experts, those who can be consulted by judges in specific legal issues or are required to assist the judge in conducting the judicial work (but do not take part in the judgment).

It is noted that the concept of forensic expert is not included in this classification, the notion of judicial technical expert or forensic expert in the European legal space being treated rather like that of a witness or scientific witness, a capacity granted by the parties or the judicial bodies, usually found in the form of a court expert (forensic expert).

\section{Bibliography}

C. Grigoraş, Judicial Expertise in Europe and the ECHR Practice, Communication Symposium, "Novelties in the Field of Forensic Science, Criminal Law and Criminal Procedure", organized by the Romanian Forensic Association, Bucharest, 2009.

Code of Conduct for forensic practitioners developed at the level of ENFSI, "CODE of CONDUCT" (BRD-GEN-003/16.6/2005);

Council Framework Decision no. 2009/905/JAI on accreditation of forensic service providers;

Government Ordinance no. 10 of 25 July 2012 by which the legal framework for the automated search of reference data in relation to the European Union Member States was created and which provides the recognition of laboratory activities regarding dactyloscopic data;

Law no.135/2010 on the New Criminal Procedure Code, published in the Official Journal of Romania, Part I, no. 486 of 15 July 2010; 
Law nr.156/2011 amending and supplementing Art. 1 of Government Ordinance no. $75 / 2000$ on the authorization of forensic experts. Published in the Official Journal of Romania, Part I, no. 519 of 22 July 2011;

The European Commission for the Efficiency of Justice, "European judicial systems, efficiency and quality of justice”, 2012, www.coe.int / cepej.

The Romanian Criminal Procedure Code;

www.coe.int/cepej. European Comission for the Efficiency of Justice, Systèmes judiciaires européens, Efficacité et qualité de la justice, Les études de la CEPEJ no.18, Editions du Conseil de l'Europe, Publishing Editions 2012.

www.csm 1909.ro

www.enfsi.eu;

www.eur-lex.europa.eu;

www.european-accreditation.org;

www.inec.ro;

www.just.ro;

www.noema.crifst.ro 